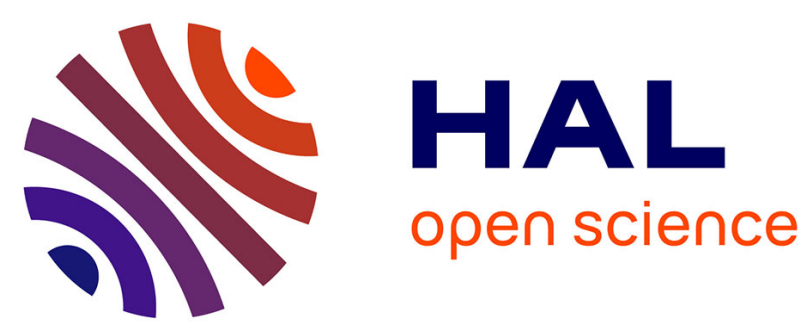

\title{
A modelling exercise on the importance of ternary alkaline earth carbonate species of uranium(VI) in the inorganic speciation of natural waters
}

\author{
Thomas Vercouter, Pascal E. Reiller, Eric Ansoborlo, Laureline Février, \\ Rodolphe Gilbin, Claire Lomenech, Violaine Philippini
}

\section{To cite this version:}

Thomas Vercouter, Pascal E. Reiller, Eric Ansoborlo, Laureline Février, Rodolphe Gilbin, et al.. A modelling exercise on the importance of ternary alkaline earth carbonate species of uranium(VI) in the inorganic speciation of natural waters. Applied Geochemistry, 2015, Geochemical Speciation Codes and Databases, 55, pp.192-198. 10.1016/j.apgeochem.2014.11.016 . hal-01313947

\section{HAL Id: hal-01313947 \\ https://hal.science/hal-01313947}

Submitted on 10 May 2016

HAL is a multi-disciplinary open access archive for the deposit and dissemination of scientific research documents, whether they are published or not. The documents may come from teaching and research institutions in France or abroad, or from public or private research centers.
L'archive ouverte pluridisciplinaire HAL, est destinée au dépôt et à la diffusion de documents scientifiques de niveau recherche, publiés ou non, émanant des établissements d'enseignement et de recherche français ou étrangers, des laboratoires publics ou privés. 


\section{A modelling exercise on the importance of ternary alkaline earth carbonate}

species of uranium(VI) in the inorganic speciation of natural waters

Thomas Vercouter $^{a,}{ }^{,}$, Pascal E. Reiller ${ }^{a}$, Eric Ansoborlo ${ }^{b}$, Laureline Février ${ }^{c}$, Rodolphe Gilbin $^{c}$, Claire Lomenech $^{d}$, Violaine Philippini $i^{e}$

${ }^{a}$ CEA, DEN, DANS, DPC, SEARS, LANIE, F-91191 Gif-sur-Yvette Cedex, France.

*corresponding author : +33169082659 (phone) / +33169089475 (fax), thomas.vercouter@cea.fr

${ }^{b}$ CEA, DEN, MAR, DRCP, CETAMA, BP 17171, 30207 Bagnols-sur-Cèze, France.

' IRSN, PRP-ENV, SERIS, L2BT, bld 183, B.P. 3, F-13115 Saint Paul-lez-Durance, France.

${ }^{d}$ Université de Nice Sophia Antipolis, Laboratory ECOMERS, 28 avenue Valrose, 06108 Nice Cedex 2,

France.

e Université de Nice Sophia Antipolis, Institut de Chimie de Nice, 28 avenue Valrose, 06108 Nice Cedex 2, France.

Keywords: Uranium, speciation, carbonate complexes, calcium, magnesium, solubility, thermodynamic calculation, natural water.

\section{Summary}

Predictive modelling of uranium speciation in natural waters can be achieved using equilibrium thermodynamic data and adequate speciation software. The reliability of such calculations is highly dependent on the equilibrium reactions that are considered as entry data, and the values chosen for the equilibrium constants. The working group "Speciation" of the CETAMA (Analytical methods establishment committee of the French Atomic Energy commission, CEA) has organized a modelling exercise, including four participants, in order to compare modellers' selections of data and test 
thermodynamic data bases regarding the calculation of $U(V I)$ inorganic speciation. Six different compositions of model waters were chosen so that to check the importance of ternary alkaline earth carbonate species of $\mathrm{U}(\mathrm{VI})$ on the aqueous speciation, and the possible uranium solid phases as solubility-limiting phases. The comparison of the results from the participants suggests i) that it would be highly valuable for end-users to review thermodynamic constants of ternary carbonate species of $\mathrm{U}(\mathrm{VI})$ in a consistent way and implement them in available speciation data bases, and ii) stresses the necessary care when using data bases to avoid biases and possible erroneous calculations.

\section{Introduction}

The availability of uranium in natural waters is governed by many processes and interactions with natural chemical compounds. Under oxic conditions uranium is usually present under the predominant redox state $+\mathrm{VI}$, i.e. in the form of uranyl ion $\left(\mathrm{UO}_{2}{ }^{2+}\right)$. Many aqueous complexes of $\mathrm{U}(\mathrm{VI})$ may form as a result of hydrolysis, complexation with inorganic anions such as (bi)carbonate, phosphate, sulphate, silicate, etc [1], or complexation with organic ligands or organic matter [2]. The nature and the charge of the $\mathrm{U}(\mathrm{VI})$ complexes determine the adsorption properties of $\mathrm{U}(\mathrm{VI})$ onto surfaces, especially on iron oxo-hydroxides [3]. At equilibrium the predominant soluble and solid forms of uranium can be estimated using thermodynamic formation constants and aqueous geochemical speciation codes. The quality of calculations is mainly related to the quality and completeness of the entry data. Moreover, the uncertainty on thermodynamic formation constants can result in considerable output uncertainty, particularly for species like uranium that undergoes a complex aqueous speciation [4]. Within the working group "Speciation" of the CETAMA (Analytical methods establishment committee of the French Atomic Energy commission, CEA) a modelling exercise was conducted about the $\mathrm{U}(\mathrm{VI})$ speciation in waters of known compositions as previously carried out for other chemical systems $[5,6]$. The objectives were: i) to test thermodynamic data 
bases; ii) to compare the modellers' methods in selecting data; and iii) to evaluate the effect of inorganic species on the $\mathrm{U}(\mathrm{VI})$ speciation and solubility.

The speciation of $\mathrm{U}(\mathrm{VI})$ in $\mathrm{H}_{2} \mathrm{O}-\mathrm{H}^{+}-\mathrm{HCO}_{3}{ }^{-}$systems has been widely studied, especially for determining the nature of the aqueous species and their concentrations. Hydrolysis and carbonate complexation are certainly the main reactions that occur in natural environments. The corresponding thermodynamic constants have been determined experimentally and reviewed by several groups, on the basis of which thermodynamic modeling can be performed. The Thermochemical Data Base project of the Atomic Energy Agency (NEA-TDB) of the OECD has particularly contributed to provide high-quality and consistent thermodynamic data for actinide compounds from experimental works in a series of comprehensive review books $[7,8]$. The NEA-TDB selected data set for uranium [9-11] is forming the basis of a lot of data banks. Because the selection process strictly follows guidelines to ensure quality and consistency of the data, the data set is inherently incomplete and must be used with a lot of caution for equilibrium calculations of natural systems. The lack of data may induce severe biases in a modelling output [12]. It might be the case for the ternary carbonate species of uranyl with major alkaline earth cations, e.g. such as $\mathrm{Ca}^{2+}$ and $\mathrm{Mg}^{2+}$. Indeed, solution species like $\mathrm{Ca}_{2} \mathrm{UO}_{2}\left(\mathrm{CO}_{3}\right)_{3}(\mathrm{aq}), \mathrm{CaUO}_{2}\left(\mathrm{CO}_{3}\right)_{3}{ }^{2-}$, and $\mathrm{MgUO}_{2}\left(\mathrm{CO}_{3}\right)_{3}{ }^{2-}$ that had been identified and characterized by some groups [13-16], were discussed but not selected by the NEA-TDB experts in the 2003 update review [11] because the reports did not fulfill the TDB guidelines. Since then, several publications have identified and reported the existence or influence of such dissolved species in environmental waters [17], in adsorption experiments [18, 19], and in contaminated soils and sediments [20, 21]. Formation data have been further determined recently [22-25]. It is of the modeller's responsibility whether to choose including new entry data or not to already existing data bases. The main motivation to do so is to take into account all the relevant stoichiometries that can exist. Nevertheless the addition of external data to an existing data bank usually causes a decrease of the internal consistency of the resulting data bank $[7,8]$. Hence it is a long-term task to improve thermodynamic data banks with newly determined data while maintaining its quality regarding 
consistency and relevance. The results of speciation calculations may be highly dependent on how the working data bank is built as shown elsewhere [12], and as it will be shown in this paper. Moreover, in the case of geochemical calculations the thermodynamic control of the species concentrations may not reflect the real geochemical system. Numerous processes - i.e. coprecipitation, adsorption, colloid formation - can occur involving ill-defined compounds - i.e. amorphous, semi-amorphous, heterogeneous compounds, metastable phases- and possibly under non-equilibrium conditions. Calculations of uranium solubility are always possible on the basis of pure uranium solid phases, which can be a first step in evaluating the solubility-controlling processes. The use of solubility products of mineral phases is therefore an important part of the geochemical modelling. Here, we should also emphasize the importance of the choice of adequate entry thermodynamic values as well as the modellers' expertise based on saturation indices and knowledge of the relevance of the compounds compared with observations. Finally, every speciation calculation software not only includes thermodynamic equilibrium equations, but also parametric equations to model the ion concentration-activity relationship or the temperature variation of thermodynamic functions. At constant and low temperature, the values of the equilibrium formation constants of the species are calculated by using reference thermodynamic values at infinite dilution, and applying a formula to account for ion activities. Many ion activity models have been developed [26], and the choice of any model may affect the output results of the geochemical calculation. Moreover consistent thermodynamic data banks are usually associated with one ion activity model that was used to derive reference data at zero ionic strength. Then using a different model or using different parameters would bias the calculations and decrease the consistency of the data.

The object of the present exercise is to test the modelling approaches using a speciation software and thermodynamic data for the evaluation of the uranium speciation in aqueous solutions representative of natural waters. No uncertainty evaluation was asked in the present exercise. Such an evaluation requires a complete assessment of all the sources of uncertainties [4, 27-29], and might be the aim of other dedicated exercises. This practical and theoretical exercise was established 
from water conditions as those found in Finnish well-waters, containing significant amounts of dissolved uranium [17]. These waters had been monitored for $\mathrm{pH}$, Eh, as well as cation and anion concentrations. The dissolved uranium contents (concentration in $\mathrm{mg} / \mathrm{L}$ ) had also been measured, which provide a useful basis for theoretical speciation calculations. Under such $\mathrm{pH}$ conditions, the carbonate species is predominantly $\mathrm{HCO}_{3}{ }^{-}$, and one may expect that $\mathrm{U}(\mathrm{VI})$ forms carbonate complexes due to its high affinity to $\mathrm{CO}_{3}{ }^{2-}$. The main purpose of the exercise is the identification of major differences in output results that can be attributed either to the entry data as chosen by the modellers or to the assumptions and related model equations.

\section{Methodology}

\section{Calculation exercise}

The data bank and the speciation software choices were left open. Each participant was requested to return the results of their calculations for each water composition, namely the nature and the proportions of dissolved uranium species. The uranium solubility was also estimated by the participants on the basis of uranium phases that may precipitate under the chemical conditions of the waters. The resulting uranium concentration could be compared with the one provided with the water composition. The participants were also asked to provide detailed information on the software used and the origin of the entry thermodynamic data.

Waters noted $\mathbf{A}$ and $\mathbf{E}$ represent two different compositions of mildly basic natural waters (Table 1 ). The water $\mathbf{A}$ has a pH of 8.4 compared with 8.0 for the water $\mathbf{E}$. The Eh values of both waters are around $200 \mathrm{mV} / \mathrm{ENH}$, and no indication of the redox buffer is available. The ion concentrations apparently have similar values, except for some ions: the $\mathrm{F}^{-}$concentration is ten times higher in $\mathbf{E}$ than in $\mathbf{A}$ while the $\mathrm{Ca}^{2+}$ concentration is five times lower in $\mathbf{E}$ than in $\mathbf{A}$. The uranium content in $\mathbf{A}$ is quite significant $(1.7 \mathrm{ppm})$ whereas it is relatively low in $\mathbf{E}(6 \mathrm{ppb})$. If equilibrium conditions are fulfilled, the latter observation suggests that the uranium solubility is highly affected by apparently small modifications of the water composition. Thus the modelling of the uranium solubility and 
species distribution would either confirm the dependence of uranium speciation on these conditions or indicate disequilibrium conditions.

In order to test the calculations, water compositions were modified on the basis of the waters $\mathbf{A}$ and E, so as to create artificial waters noted $\mathbf{B}, \mathbf{C}, \mathbf{D}$, and $\mathbf{F}$. The water $\mathbf{B}$ is made from water $\mathbf{A}$ while the ionic strength was increased by adding $\mathrm{NaCl}$ up to $100 \mathrm{mmol} / \mathrm{L}$, and should be able to assess whether ion activity calculations are of importance in the modelling. In water $\mathbf{C}$, the bicarbonate content was decreased by a factor of 100 compared to the content in $\mathbf{A}$. The $\mathrm{Mg}^{2+}$ concentration in water $\mathbf{D}$ was increased by a factor of three compared to water $\mathbf{A}$ in order to assess the effect on the stability of specific ternary uranium species. The water $\mathbf{F}$ is made from water $\mathbf{E}$ with a $\mathrm{pH}$ value lowered by one unit and $\mathrm{Ca}^{2+}$ was decreased by a factor 2 .

Table 1: Composition of waters at 1 bar and $20^{\circ} \mathrm{C}$ used for the modelling of uranium speciation. The waters $\mathbf{A}$ and $\mathbf{E}$ have the composition of natural waters (bold) as experimentally determined in [17] while some ion concentrations (underlined) in the waters B, C, D, F have been modified.

\begin{tabular}{|c|c|c|c|c|c|c|}
\hline & $\bar{A}$ & $\mathbf{B}$ & $\mathbf{C}$ & D & $\bar{E}$ & $\bar{F}$ \\
\hline$\overline{\mathrm{pH}}$ & 8.42 & 8.42 & 8.42 & 8.42 & 8.03 & $\underline{7}$ \\
\hline Eh $(m V)$ & 166 & 166 & 166 & 166 & 213 & 213 \\
\hline Total Uranium $(\mu \mathrm{g} / \mathrm{L})$ & 1754 & 1754 & 1754 & 1754 & 5.6 & 5.6 \\
\hline $\mathrm{HCO}_{3}{ }^{-}(\mathrm{mM})$ & 3.1 & 3.1 & $\underline{0.03}$ & $\underline{4}$ & 2.16 & 2.16 \\
\hline$F^{-}(\mu M)$ & 25.6 & 25.6 & 25.6 & 25.6 & 237.9 & 237.9 \\
\hline $\mathrm{Cl}^{-}(\mu \mathrm{M})$ & 305 & 100000 & $\underline{3500}$ & 305 & 406 & 406 \\
\hline $\mathrm{NO}_{2}^{-}(\mu \mathrm{M})$ & 2.17 & 2.17 & 2.17 & 2.17 & 2.17 & 2.17 \\
\hline $\mathrm{NO}_{3}^{-}(\mu \mathrm{M})$ & 18.1 & 18.1 & 18.1 & 18.1 & 1.9 & 1.9 \\
\hline $\mathrm{SO}_{4}{ }^{2-}(\mu \mathrm{M})$ & 245 & 245 & 245 & 245 & 120 & 120 \\
\hline $\begin{array}{l}\text { Total phosphate } \\
(\mu \mathrm{M})\end{array}$ & 2.21 & 2.21 & 2.21 & 2.21 & 2.21 & 2.21 \\
\hline $\mathrm{Li}^{+}(\mu \mathrm{M})$ & 1.2 & 1.2 & 1.2 & 1.2 & 1.58 & 1.58 \\
\hline $\mathrm{Na}^{+}(\mathrm{mM})$ & 1.63 & 100 & 1.63 & 1.63 & 2.56 & 2.56 \\
\hline $\mathrm{NH}_{4}{ }^{+}(\mu \mathrm{M})$ & 17.7 & 17.7 & 17.7 & 17.7 & 16.6 & 16.6 \\
\hline $\mathrm{K}^{+}(\mu \mathrm{M})$ & 57.3 & 57.3 & 57.3 & 57.3 & 79 & 79 \\
\hline $\mathrm{Mg}^{2+}(\mu \mathrm{M})$ & 317 & 317 & 317 & $\underline{1000}$ & 97 & 97 \\
\hline $\mathrm{Ca}^{2+}(\mathrm{mM})$ & 1 & 1 & 1 & $\underline{0.09}$ & 0.2 & $\underline{0.1}$ \\
\hline $\mathrm{Sr}^{2+}(\mu \mathrm{M})$ & 1.85 & 1.85 & 1.85 & 1.85 & 0.68 & 0.68 \\
\hline Silicium $(\mu \mathrm{M})$ & 203 & 203 & 203 & 203 & 253 & 253 \\
\hline
\end{tabular}


Two speciation softwares have been used by the participants. The PhreeqC software in its versions 2.10, 2.11 and 2.17 [30] has been used by the participants 1, 2, and 3, while JChess 2.0 [31] has been used by participant 4 . Participant 1 reported that preliminary tests were made with the Medusa software [32], but convergence was hardly obtained probably due to the too high number of species; this software was no more used for the present exercise.

The data bases varied from one participant to another (Table 2). Participants $\mathbf{1}$ and $\mathbf{4}$ provided results from two slightly different calculation sets, hereafter denoted $\mathbf{1} \mathbf{a}, \mathbf{1} \mathbf{b}, \mathbf{4} \mathbf{a}$, and $\mathbf{4 b}$. Participant $\mathbf{1 a}$ used the LLNL (Lawrence Livermore National Laboratory) data base [33] using the IInl.dat database file provided within the PhreeqC package and based on the file thermo.com.V8.R6.230 (8 March 2000). A second set is proposed (1) in which the core data base is coming from the NEA-TDB recommendation [11], and completed when necessary with data from the LLNL data base. The participant 2 has also used the LLNL data from the EQ3/6 software [33], completed with data from the NEA-TDB selection [11], and from [22] for ternary uranium-carbonate complexes. The participant $\mathbf{3}$ has used the Thermochimie data base provided as the sit.dat file of the PhreeqC package, which is mainly based on the NEA-TDB selection; complexation constant from $[22,23]$ were added to the entry data set for $\mathrm{Ca} / \mathrm{Mg}-\mathrm{U}$-carbonate species. The participant $\mathbf{4}$ has used data as compiled in the Common Thermodynamic Database Project (CTDP) released in 2004 [34] in a first set of calculation (4a). The database was based on the merger of the review of thermodynamic data mainly originated from the NEA-TDB critical selection for $U$ performed by Denison [35] and the LLNL database (chess.tdb). A second set of calculation (4b) was provided with the same entry data completed with formation constants for $\mathrm{Ca} / \mathrm{Mg}-\mathrm{U}$-carbonate species from [22-24]. The solubility products of the $\mathrm{U}(\mathrm{VI})$ solid phases that were reported by the participants in their calculations are compiled in Table S1 of the Supplmentary Information in order to better compare the differences and similarities. 
Table 2: Calculation methods as used by the participants.

\begin{tabular}{|c|c|c|c|c|c|c|}
\hline Participant ID & 1a & $1 \mathrm{~b}$ & 2 & 3 & $4 a$ & $4 b$ \\
\hline Software & $\begin{array}{l}\text { PHREEQC } \\
2.11[30] \\
\end{array}$ & $\begin{array}{l}\text { PHREEQC } \\
2.11[30] \\
\end{array}$ & $\begin{array}{l}\text { PHREEQC } 2.10 \\
{[30]}\end{array}$ & $\begin{array}{l}\text { PHREEQC } \\
2.17[30] \\
\end{array}$ & $\begin{array}{l}\text { JChess } 2.0 \\
{[31]}\end{array}$ & JChess 2.0 [31] \\
\hline Data bases & LLNL [33] & $\begin{array}{l}\text { NEA-TDB } \\
\text { completed } \\
\text { with LLNL } \\
\text { [33] }\end{array}$ & $\begin{array}{l}\text { LLNL [33] + NEA- } \\
\text { TDB } \\
+ \text { data from [22] }\end{array}$ & $\begin{array}{l}\text { Thermochimie } \\
\text { + data from } \\
{[22,23]}\end{array}$ & $\begin{array}{l}\text { CTDP } 2004 \\
{[34]}\end{array}$ & $\begin{array}{l}\text { CTDP } 2004[34]+ \\
\text { data from [22-24] }\end{array}$ \\
\hline $\begin{array}{l}\text { Ion activity } \\
\text { models }\end{array}$ & Davies & Davies & Davies & SIT & $\begin{array}{l}\text { Truncated- } \\
\text { Davies }\end{array}$ & $\begin{array}{l}\text { Truncated- } \\
\text { Davies }\end{array}$ \\
\hline
\end{tabular}

The ionic strength effect on the ion concentrations was taken into account using different equations implemented in the softwares. The Davies and truncated-Davies equations were used by the participants 1, 2, and $\mathbf{4}$. These equations do not require any entry parameters. The participant $\mathbf{3}$ used the Specific ion Interaction Theory (SIT), used to calculate thermodynamic data within the NEA-TDB reviews and implemented in the PhreeqC 2.17 version. The binary interaction parameters $\varepsilon$ are provided in the sit.dat file and set to 0 by default when not available [36].

\section{Results}

Solution A. The soluble uranium species were predicted by all the participants to be dominated by carbonate complexes (Figure 1). Participants $\mathbf{2 , 3}$ and $\mathbf{4 b}$ included as input data the formation data of the ternary calcium carbonate soluble species from [22]. Consequently, they all predicted $\mathrm{Ca}_{2} \mathrm{UO}_{2}\left(\mathrm{CO}_{3}\right)_{3}(\mathrm{aq})$ and $\mathrm{CaUO}_{2}\left(\mathrm{CO}_{3}\right)_{3}{ }^{2-}$ to be the major species of uranium, i.e. at about $61 \%$ and $38 \%$, respectively. Participant 4a tested the formation data reported by [13], which induce differences in the proportions of these species at $87 \%$ and $8 \%$, respectively. Other species like $\mathrm{MgUO}_{2}\left(\mathrm{CO}_{3}\right)_{3}{ }^{2-}$, $\mathrm{UO}_{2}\left(\mathrm{CO}_{3}\right)_{3}{ }^{4-}$, and $\mathrm{UO}_{2}\left(\mathrm{CO}_{3}\right)_{2}{ }^{2-}$ were less than $5 \%$. On the contrary, participant 1 used the LLNL data base (1a) or the NEA-TDB completed with data from the LLNL data base (1b). None of these input data banks contain formation data for ternary ( $\mathrm{Ca}$ or $\mathrm{Mg}$ ) carbonate species of $\mathrm{U}(\mathrm{VI})$. As a consequence, the main species were $\mathrm{UO}_{2}\left(\mathrm{CO}_{3}\right)_{3}{ }^{4-}(70 \%$ and $90 \%)$ and $\mathrm{UO}_{2}\left(\mathrm{CO}_{3}\right)_{2}{ }^{2-}(26 \%$ and $8 \%)$ in the simulations by $\mathbf{1 a}$ and $\mathbf{1 b}$, respectively. 


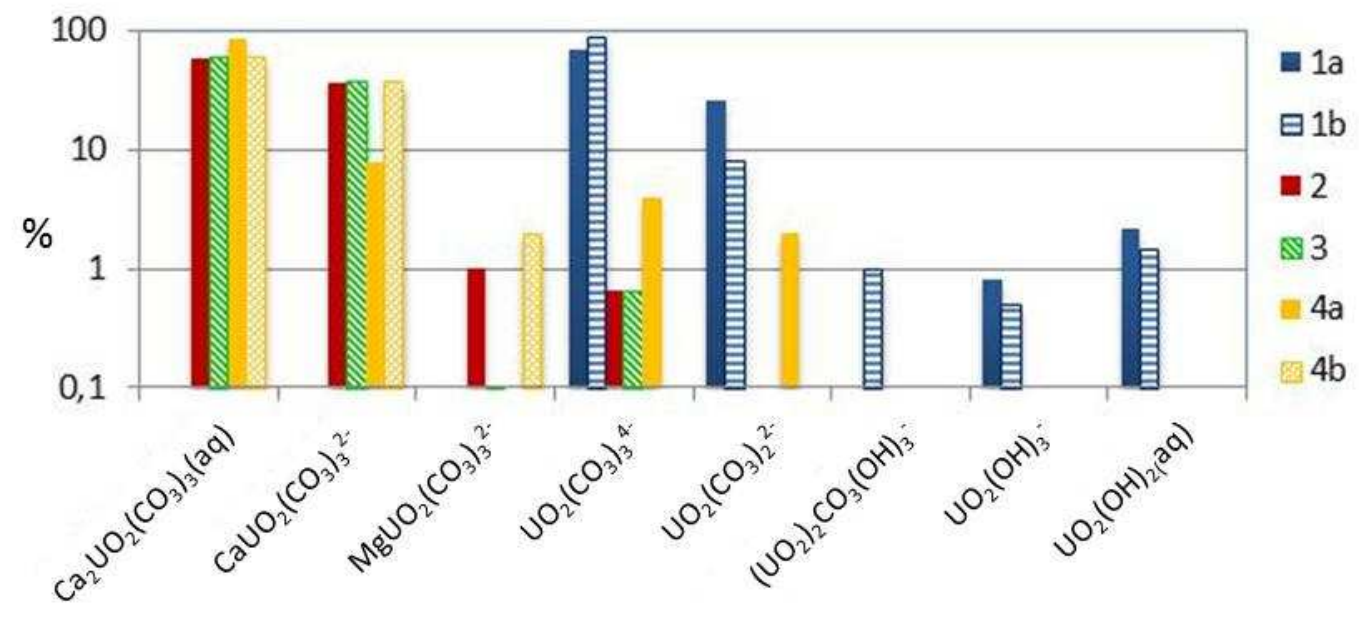

Figure 1: Comparison of the proportions of uranium carbonate complexes calculated by the participants for the water $\mathbf{A}$.

The total uranium concentration was evaluated by each participant by allowing solid phases to precipitate and compared with the reported uranium content reported in Table 1. Participants $\mathbf{1 b} \mathbf{2} \mathbf{2}$, $\mathbf{3}$, and $\mathbf{4}$ found that the water $\mathrm{A}$ is undersaturated with respect to all uranium phases. Participant $\mathbf{2}$ also reported that compregnacite $\left(\mathrm{K}_{2} \mathrm{U}_{6} \mathrm{O}_{19}, 11 \mathrm{H}_{2} \mathrm{O}\right)$ had a large saturation index in its simulations whatever the type of water, but was considered irrelevant because it would have led to extremely low solubility values incompatible with natural uranium solubilities; the precipitation of this phase was further suppressed by Participant 3. Participant 4 calculated uranium soluble content of 16 and $69 \mathrm{mg} / \mathrm{L}$ for calcium uranate $\left(\mathrm{CaUO}_{4}\right)$, and 158 and $194 \mathrm{mg} / \mathrm{L}$ for (meta)schoepite $\left(\mathrm{UO}_{3}, 2 \mathrm{H}_{2} \mathrm{O}\right)$ in calculations $\mathbf{4 a}$ and $\mathbf{4} \mathbf{b}$, respectively. All these values were indeed higher by more than one order of magnitude than the measured uranium concentration in water A. On the contrary, participant 1a calculated that water $A$ is oversaturated with respect to soddyite, which induces a solubility of uranium of $0.09 \mathrm{mg} / \mathrm{L}$, twenty times lower than the uranium concentration reported in table 1.

Solution B. The composition of this water is similar to that of solution A, but containing higher amount of $\mathrm{NaCl}$ (300 times more). Participant 1 has not included ternary calcium carbonate species 
and proposed that $\mathrm{UO}_{2}\left(\mathrm{CO}_{3}\right)_{3}{ }^{4-}$ is the major species (more than 96\%). In the calculation by participants $\mathbf{2}, \mathbf{3}$, and $\mathbf{4 b}$, the dominant aqueous species were found to be $\mathrm{CaUO}_{2}\left(\mathrm{CO}_{3}\right)_{3}{ }^{2-}$ (between 48 and 61\%), $\mathrm{Ca}_{2} \mathrm{UO}_{2}\left(\mathrm{CO}_{3}\right)_{3}(\mathrm{aq})$ (between 26 and $38 \%$ ), and $\mathrm{UO}_{2}\left(\mathrm{CO}_{3}\right)_{3}{ }^{4-}$ (between 10 and $14 \%$ ). The proportions obtained by participant $4 \mathrm{a}$ is somewhat different: $\mathrm{Ca}_{2} \mathrm{UO}_{2}\left(\mathrm{CO}_{3}\right)_{3}(\mathrm{aq})(25 \%), \mathrm{CaUO}_{2}\left(\mathrm{CO}_{3}\right)_{3}{ }^{2-}$ (8\%), and $\mathrm{UO}_{2}\left(\mathrm{CO}_{3}\right)_{3}{ }^{4-}(65 \%)$, as a result of the formation constant from [13] instead of that of [22]. Compared with the results for solution $\mathbf{A}$, the increased ionic strength at about $0.1 \mathrm{M}$ stabilizes the charged complexes leading to larger amounts of $\mathrm{CaUO}_{2}\left(\mathrm{CO}_{3}\right)_{3}{ }^{2-}$ and $\mathrm{UO}_{2}\left(\mathrm{CO}_{3}\right)_{3}{ }^{4-}$ than $\mathrm{Ca}_{2} \mathrm{UO}_{2}\left(\mathrm{CO}_{3}\right)_{3}(\mathrm{aq})$. The use of different ion activity coefficient models (Davies, truncated-Davies, SIT) has no significant effect on the calculated proportions, which is quite reasonable in view of the moderate ionic strength [26].

The results for the solid phases were similar to those reported for water $\mathbf{A}$ by the participants, except in the case of participant 1a who calculated a uranium solubility of $1 \mathrm{mg} / \mathrm{L}$ controlled by soddyite, close to the $1.7 \mathrm{mg} / \mathrm{L}$ indicated in Table 1 . It should be noted that this latter value does not correspond to any measurements on the contrary to water $\mathbf{A}$, thus the comparison is only indicative.

Solution $\mathbf{C}$. The composition of this water is similar to that of solution $\mathbf{A}$, except that the bicarbonate content has been reduced to the hundredth. As a consequence the carbonate species are much less stable under these conditions. Several solid phases were reported as oversaturated phases as indicated in Table 3. Participant 1a found that the resulting aqueous species were $\mathrm{UO}_{2}(\mathrm{OH})_{2}(\mathrm{aq})$ and $\mathrm{UO}_{2}(\mathrm{OH})_{3}{ }^{-}$. The main species as proposed by participant $\mathbf{1 b}$ are $\left(\mathrm{UO}_{2}\right)_{2} \mathrm{CO}_{3}(\mathrm{OH})_{3}{ }^{-}, \mathrm{UO}_{2}(\mathrm{OH})_{3}^{-}$, and $\mathrm{UO}_{2}\left(\mathrm{CO}_{3}\right)_{2}{ }^{2-}$. Participant $\mathbf{2}$ noticed that many uranium solid phases were oversaturated in solution $\mathbf{C}$ : uranophane, becquerelite $\left(\mathrm{CaU}_{6} \mathrm{O}_{19}: 11 \mathrm{H}_{2} \mathrm{O}\right)$ calcium uranate, Na-Boltwoodite $\left(\mathrm{NaUO}_{2} \mathrm{SiO}_{3} \mathrm{OH}: 1.5 \mathrm{H}_{2} \mathrm{O}\right)$, soddyite, (meta)schoepite. Again, the uranium content in water $\mathrm{C}$ indicated in Table 1 is not a measured value. Uranophane, soddyite and (meta)schoepite were supposed to be the most relevant phases in the case of solution $\mathbf{C}$ but becquerelite was not tested although it is known to control uranium(VI) solubility in Ca rich waters [37]; when precipitation of uranophane was 
allowed, the resulting $\mathrm{pH}(8.3)$ was close to the initial 8.42 value, and four uranium soluble species were present at similar amount: $\mathrm{Ca}_{2} \mathrm{UO}_{2}\left(\mathrm{CO}_{3}\right)_{3}(\mathrm{aq}), \mathrm{CaUO}_{2}\left(\mathrm{CO}_{3}\right)_{3}{ }^{2-}, \mathrm{UO}_{2}(\mathrm{OH})_{2}(\mathrm{aq})$, and $\mathrm{UO}_{2}(\mathrm{OH})_{3}{ }^{-}$. The solubility of soddyite and (meta)schoepite were found to be similar under the conditions of solution C, and the $\mathrm{pH}$ was calculated at 8.5. In this case, the solution speciation was dominated by the mixed hydroxo-carbonate complex $\left(\mathrm{UO}_{2}\right)_{2} \mathrm{CO}_{3}(\mathrm{OH})_{3}{ }^{-}$, as also found by participant 3. Participant 4 observed in both calculations $\mathbf{4 a}$ and $\mathbf{4 b}$ that calcium uranate precipitated as a result of the diminution of $\mathrm{HCO}_{3}^{-}$ and $\mathrm{Cl}^{-}$that enables $\mathrm{Ca}^{2+}$ to be available for precipitation with other compounds; consequently a very low solubility of about $1 \mu \mathrm{g} / \mathrm{L}$ was calculated due to $\mathrm{CaUO}_{4}$. When calcium uranate precipitation was not allowed, the uranium solubility was controlled by (meta)schoepite leading to a solubility of about $2.1 \mathrm{mg} / \mathrm{L}$.

Table 3: Solid phases proposed as possible uranium solubility-controlling phases in water C.

\begin{tabular}{|c|c|c|c|}
\hline Participant ID & Solid phase & $\begin{array}{l}\text { Calculated } \\
\mathrm{U}(\mathrm{VI}) \text { solubility } \\
\mu \mathrm{mol} / \mathrm{L}\end{array}$ & $\begin{array}{l}\text { Calculated } \\
\mathrm{U}(\mathrm{VI}) \text { solubility } \\
\mu \mathrm{g} / \mathrm{L}\end{array}$ \\
\hline $1 a$ & $\begin{array}{l}\text { Soddyite } \\
\left(\mathrm{UO}_{2}\right)_{2} \mathrm{SiO}_{4}, 2 \mathrm{H}_{2} \mathrm{O}\end{array}$ & $2.10^{-2}$ & 4.8 \\
\hline $1 b$ & $\begin{array}{l}\text { Compregnacite } \\
\mathrm{K}_{2} \mathrm{U}_{6} \mathrm{O}_{19}, 11 \mathrm{H}_{2} \mathrm{O}\end{array}$ & 1.8 & 428 \\
\hline \multirow[t]{3}{*}{2} & $\begin{array}{l}\text { Uranophane } \\
\mathrm{Ca}\left(\mathrm{UO}_{2}\right)_{2}\left(\mathrm{SiO}_{3} \mathrm{OH}\right) 2,5 \mathrm{H}_{2} \mathrm{O}\end{array}$ & 3.2 & 762 \\
\hline & $\begin{array}{l}\text { (meta)Schoepite } \\
\mathrm{UO}_{3}, 2 \mathrm{H}_{2} \mathrm{O}\end{array}$ & 4.7 & 1119 \\
\hline & $\begin{array}{l}\text { Soddyite } \\
\left(\mathrm{UO}_{2}\right)_{2} \mathrm{SiO}_{2}, 2 \mathrm{H}_{2} \mathrm{O} \\
\end{array}$ & 4.7 & 1119 \\
\hline 3 & Not given & Not given & Not given \\
\hline \multirow[t]{2}{*}{$4 a$} & $\begin{array}{l}\text { Calcium uranate } \\
\mathrm{CaUO}_{4}\end{array}$ & $4.10^{-3}$ & 0.92 \\
\hline & $\begin{array}{l}\text { (meta)Schoepite } \\
\mathrm{UO}_{3}, 2 \mathrm{H}_{2} \mathrm{O}\end{array}$ & 8.8 & 2100 \\
\hline \multirow[t]{2}{*}{$4 b$} & $\begin{array}{l}\text { Calcium uranate } \\
\mathrm{CaUO}_{4}\end{array}$ & $4.10^{-3}$ & 1.1 \\
\hline & $\begin{array}{l}\text { (meta)Schoepite } \\
\mathrm{UO}_{3}, 2 \mathrm{H}_{2} \mathrm{O}\end{array}$ & 8.8 & 2100 \\
\hline
\end{tabular}

Solution D. The composition of this water is similar to that of solution A, except that the magnesium content is more than three times higher. The bicarbonate content has also been slightly increased to 
balance the charges. Because only participants 2, 3, and $4 \mathrm{~b}$ included formation constant for $\mathrm{MgUO}_{2}\left(\mathrm{CO}_{3}\right)_{3}{ }^{2-}$, differences in the distribution of the aqueous species were observed. Participants 2 and $\mathbf{4 b}$ both calculated equimolar concentrations of $\mathrm{MgUO}_{2}\left(\mathrm{CO}_{3}\right)_{3}{ }^{2-}$ and $\mathrm{CaUO}_{2}\left(\mathrm{CO}_{3}\right)_{3}{ }^{2-}$ (about $43 \%$ each) while $\mathrm{Ca}_{2} \mathrm{UO}_{2}\left(\mathrm{CO}_{3}\right)_{3}(\mathrm{aq})$ and $\mathrm{UO}_{2}\left(\mathrm{CO}_{3}\right)_{3}{ }^{4-}$ represent between 5 and $9 \%$ of the total aqueous species of $\mathrm{U}(\mathrm{VI})$. Participant 3, who has used a lower value for the formation constant of $\mathrm{MgUO}_{2}\left(\mathrm{CO}_{3}\right)_{3}{ }^{2-}$, obtained the same species but in different proportions: $\mathrm{CaUO}_{2}\left(\mathrm{CO}_{3}\right)_{3}{ }^{2-}$ is the major complex (69\%), $\mathrm{UO}_{2}\left(\mathrm{CO}_{3}\right)_{3}{ }^{4-}, \mathrm{Ca}_{2} \mathrm{UO}_{2}\left(\mathrm{CO}_{3}\right)_{3}(\mathrm{aq})$, and $\mathrm{MgUO}_{2}\left(\mathrm{CO}_{3}\right)_{3}{ }^{2-}$ represent $14 \%, 9 \%$, and $5 \%$, respectively. Participant 4a did not include $\mathrm{MgUO}_{2}\left(\mathrm{CO}_{3}\right)_{3}{ }^{2-}$ in the entry data and found that $\mathrm{UO}_{2}\left(\mathrm{CO}_{3}\right)_{3}{ }^{4-}$ dominates at $70 \%$, while $\mathrm{Ca}_{2} \mathrm{UO}_{2}\left(\mathrm{CO}_{3}\right)_{3}(\mathrm{aq}), \mathrm{CaUO}_{2}\left(\mathrm{CO}_{3}\right)_{3}{ }^{2-}$, and $\mathrm{UO}_{2}\left(\mathrm{CO}_{3}\right)_{2}{ }^{2-}$ represent about $10 \%$ each. Participant $\mathbf{1 a}$ and $\mathbf{1 b}$ obtained $\mathrm{UO}_{2}\left(\mathrm{CO}_{3}\right)_{3}{ }^{4-}$ as the major species - i.e. $84 \%$ and $95 \%$, respectively-, and $\mathrm{UO}_{2}\left(\mathrm{CO}_{3}\right)_{2}{ }^{2-}$ as the minor one.

This water composition was found to be oversaturated with a few $\mathrm{Mg}$ minerals like sepiolite $\mathrm{Mg}_{4} \mathrm{Si}_{6} \mathrm{O}_{15}(\mathrm{OH})_{2} \cdot 6 \mathrm{H}_{2} \mathrm{O}$ and magnesite $\mathrm{MgCO}_{3}$ (participant 4) or dolomite $\mathrm{CaMg}\left(\mathrm{CO}_{3}\right)_{2}$ (participant 2). The precipitation of these minerals has not been allowed in the calculations. Participants $\mathbf{2}$ and $\mathbf{4}$ found that no $\mathrm{U}(\mathrm{VI})$ solid phase was oversaturated (except compregnacite as in all other calculations for participant 2) regarding the indicative uranium content (Table 1). Participant 4 calculated the theoretical U(VI) solubility if it was controlled by either calcium uranate or (meta)schoepite, leading to uranium soluble content of 32 and $191 \mathrm{mg} / \mathrm{L}$ for calcium uranate, and 191 and $225 \mathrm{mg} / \mathrm{L}$ for (meta)schoepite in calculations $\mathbf{4 a}$ and $\mathbf{4 b}$, respectively. Participant $\mathbf{1}$ found that soddyite was oversaturated and calculated the resulting $\mathrm{U}(\mathrm{VI})$ solubility to be about $1 \mathrm{mg} / \mathrm{L}$.

Solution E. Calcium carbonate complexes of $\mathrm{U}(\mathrm{VI})$ dominate the aqueous speciation according to participants 2,3 , and $\mathbf{4 b}$, with around $67 \%$ of $\mathrm{CaUO}_{2}\left(\mathrm{CO}_{3}\right)_{3}{ }^{2-}$, and $25 \%$ of $\mathrm{Ca}_{2} \mathrm{UO}_{2}\left(\mathrm{CO}_{3}\right)_{3}(\mathrm{aq})$. The other carbonate complexes, $\mathrm{UO}_{2}\left(\mathrm{CO}_{3}\right)_{3}{ }^{4-}, \mathrm{UO}_{2}\left(\mathrm{CO}_{3}\right)_{2}{ }^{2-}$, and $\mathrm{MgUO}_{2}\left(\mathrm{CO}_{3}\right)_{3}{ }^{2-}$, represent between 0 and $5 \%$ each. In the calculation by participant $4 \mathrm{a}$, different proportions have been found $-\mathrm{Ca}_{2}{\cup \mathrm{O}_{2}}_{2}\left(\mathrm{CO}_{3}\right)_{3}(\mathrm{aq})$ 
(38\%), $\mathrm{CaUO}_{2}\left(\mathrm{CO}_{3}\right)_{3}{ }^{2-}(13 \%), \mathrm{UO}_{2}\left(\mathrm{CO}_{3}\right)_{3}{ }^{4-}(27 \%)$, and $\mathrm{UO}_{2}\left(\mathrm{CO}_{3}\right)_{2}{ }^{2-}(20 \%)$. Participant 1 proposed a predominance of the complex $\mathrm{UO}_{2}\left(\mathrm{CO}_{3}\right)_{3}{ }^{4-}$ at $53 \%(1 \mathrm{a})$ or $83 \%(\mathbf{1 b})$, in coexistence with $\mathrm{UO}_{2}\left(\mathrm{CO}_{3}\right)_{2}{ }^{2-}$.

The uranium content of $5.6 \mu \mathrm{g} / \mathrm{L}$ was found to be under the precipitation limits of uranium solid phases. Only participant 4 reported calculated uranium solubilities regarding calcium uranate, i.e. 10

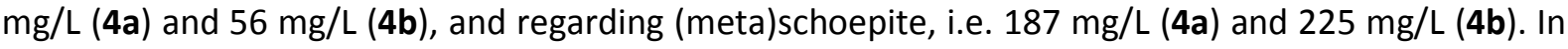
all cases, both phases were undersaturated.

Solution F. Participants 2, 3, and $\mathbf{4 b}$ obtained proportions of $\mathrm{CaUO}_{2}\left(\mathrm{CO}_{3}\right)_{3}{ }^{2-}$ between $47 \%$ and $56 \%$, $\mathrm{UO}_{2}\left(\mathrm{CO}_{3}\right)_{2}{ }^{2-}$ between $21 \%$ and $32 \%, \mathrm{Ca}_{2} \mathrm{UO}_{2}\left(\mathrm{CO}_{3}\right)_{3}(\mathrm{aq})$ at about $10 \%$, and $\mathrm{UO}_{2}\left(\mathrm{CO}_{3}\right)_{3}{ }^{4-}$ between $3 \%$ and 7\%. Participant 4a obtained a large predominance of $\mathrm{UO}_{2}\left(\mathrm{CO}_{3}\right)_{2}{ }^{2-}$ at $81 \%$, while the other carbonate complexes contributed between 2 and $8 \%$ of the total aqueous content. Participant 1a found a predominance of $\mathrm{UO}_{2}\left(\mathrm{CO}_{3}\right)_{3}{ }^{4-}$ at $80 \%$, and the presence of $\mathrm{UO}_{2}\left(\mathrm{CO}_{3}\right)_{2}{ }^{2-}, \mathrm{UO}_{2} \mathrm{CO}_{3}(\mathrm{aq})$, and $\mathrm{UO}_{2}(\mathrm{OH})_{2}(\mathrm{aq})$ at $10 \%, 5 \%$, and $5 \%$, respectively. In calculation $1 \mathrm{~b}, 50 \%$ is in the form of $\mathrm{UO}_{2}\left(\mathrm{CO}_{3}\right)_{2}{ }^{2-}$, and $\mathrm{UO}_{2}\left(\mathrm{CO}_{3}\right)_{3}{ }^{4-}$ and $\mathrm{UO}_{2} \mathrm{CO}_{3}(\mathrm{aq})$ are present at $23 \%$ and $10 \%$, respectively.

The uranium content of $5.6 \mu \mathrm{g} / \mathrm{L}$ was found to be under the precipitation limits of uranium solid phases. Only participant 4 reported calculated uranium solubilities regarding $\left(\left(\mathrm{UO}_{2}\right)_{3}\left(\mathrm{PO}_{4}\right)_{2}: 6 \mathrm{H}_{2} \mathrm{O}\right)$, i.e. $49 \mathrm{mg} / \mathrm{L}(\mathbf{4 a})$ and $54 \mathrm{mg} / \mathrm{L}$ (4b), and regarding (meta)schoepite, i.e. $74 \mathrm{mg} / \mathrm{L}$ (4a) and $90 \mathrm{mg} / \mathrm{L}$ (4b). In all cases, both phases were undersaturated.

\section{Discussion}

Solution speciation. It can be noticed that the species concentrations obtained by the participants $\mathbf{2}$, 3 and $\mathbf{4 b}$ are similar within $10-15 \%$ with two different calculation softwares PhreeqC and JChess. Indeed the same chemical model and almost the same entry data have been used on the basis of the NEA-TDB selection and with the addition of formation constants for ternary carbonate species. The main difference originates in the choice for the formation of $\mathrm{MgUO}_{2}\left(\mathrm{CO}_{3}\right)_{3}{ }^{2-}$ for which participant 3 has used the formation constant reported in [23] $-\log \beta_{1,1,3}{ }^{\circ}=26.1$ - whilst participants 2 and $\mathbf{4 b}$ 
have used the one reported in [22], which is slightly lower $-\log \beta_{1,1,3}{ }^{\circ}=25.8$. The results proposed by participant $4 a$ are significantly different mainly because of the stability constants used for $\mathrm{CaUO}_{2}\left(\mathrm{CO}_{3}\right)_{3}{ }^{2-}$ and $\mathrm{Ca}_{2} \mathrm{UO}_{2}\left(\mathrm{CO}_{3}\right)_{3}(\mathrm{aq})$ taken from [13]. Participant 1 has not included these species, and obtained very different results for the species distribution compared to the other participants as a result of the different chemical model.

The ternary carbonate species with Sr and Ba were not observed in significant amount by any of the participants although participants 2, 3, and 4 included formation data from [22]. The waters used in the present exercise contain low amounts of $\mathrm{Sr}^{2+}$ compared with $\mathrm{Ca}^{2+}$ and $\mathrm{Mg}^{2+}$ (more than two hundred times lower), and $\mathrm{Ba}^{2+}$ was not indicated, suggesting very small concentrations. Thus complexes with $\mathrm{Sr}$ or Ba could not have showed up in significant amount in the calculated speciation.

Several values of the formation constants for the calcium and magnesium ternary carbonate species are available in the literature (Table 4). The stability of the $\mathrm{Ca}_{2} \mathrm{UO}_{2}\left(\mathrm{CO}_{3}\right)_{3}(\mathrm{aq})$ species ranges within one logarithmic unit. The extreme values do not overlap according to their uncertainties. In the case of $\mathrm{CaUO}_{2}\left(\mathrm{CO}_{3}\right)_{3}{ }^{2-}$, three different experimental values by TRLFS and anion exchange are reported. The lowest one, i.e. $\log \beta_{1,1,3^{\circ}}=25.4$ [14], seems to have been re-evaluated at 26.93 by the authors in a later publication [24]. Thus, the determinations agree well within their uncertainties.

Table 4: Formation constants $\log \beta^{\circ}$ of ternary carbonate uranyl complexes at $25^{\circ} \mathrm{C}$ and $\mathrm{l}=0$ as extrapolated using the Davies formula or the SIT formula when noted.

\begin{tabular}{|c|c|c|c|c|}
\hline Method & $\mathrm{CaUO}_{2}\left(\mathrm{CO}_{3}\right)_{3}{ }^{2-}$ & $\mathrm{Ca}_{2} \mathrm{UO}_{2}\left(\mathrm{CO}_{3}\right)_{3}(\mathrm{aq})$ & $\mathrm{MgUO}_{2}\left(\mathrm{CO}_{3}\right)_{3}{ }^{2-}$ & Ref. \\
\hline TRLFS $^{\mathrm{a}}$ & - & $29.4 \pm 0.7$ & - & [13] \\
\hline TRLFS & - & $29.8 \pm 0.7$ & - & [15] \\
\hline TRLFS & $25.4 \pm 0.25$ & $30.55 \pm 0.25$ & - & [14] \\
\hline Anion exchange resin & $27.18 \pm 0.06$ & $30.70 \pm 0.05$ & $26.11 \pm 0.04$ & {$[22]$} \\
\hline Anion exchange resin & - & - & $25.8 \pm 0.5$ & [23] \\
\hline Anion exchange resin & - & - & $25.02 \pm 0.08(\mathrm{SIT})$ & [23] \\
\hline TRLFS & $26.93 \pm 0.25^{\mathrm{b}}$ & $30.79 \pm 0.29^{b}$ & $26.24 \pm 0.13$ & [24] \\
\hline TRLFS & $27.27 \pm 0.14^{\mathrm{C}}(\mathrm{SIT})$ & $29.81 \pm 0.19^{\mathrm{c}}(\mathrm{SIT})$ & - & [25] \\
\hline
\end{tabular}




\section{${ }^{\mathrm{a}}$ Time Resolved Laser Fluorescence Spectroscopy}

${ }^{b}$ Value reported in Table 2 of reference [24] and attributed to [14], suggesting a re-evaluation of the original data.

${ }^{\mathrm{C}}$ This value is reported in the publication but is different to the value obtained in the data treatment, suggestion a possible confusion in the report.

The values provided for the stability of the $\mathrm{MgUO}_{2}\left(\mathrm{CO}_{3}\right)_{3}{ }^{2-}$ species agree well within their uncertainty ranges. One value, deduced from zero ionic strength extrapolation using the SIT equation, is however significantly lower than the others, suggesting that the type of model used for ion activities corrections may induce significant differences on formation constants. It must then be recommended to select carefully entry data that have been determined using the same ion activity model to maintain consistency and avoid bias. Uncertainty evaluation on the resulting calculations was not included in the present exercise. However any calculated distribution of species or solubility should ideally be provided with uncertainty ranges [27-29], or at least must be used as indicative results on the chemical system.

As a preliminary conclusion about the aqueous solution speciation, it appears clearly that the completion of the entry data bases of speciation codes is a prerequisite to correctly predict the main species. The values attributed to each equilibrium constant are often taken from existing data bases, but they may not include some reported data either because they are too recently determined or because of the methodology used, e.g. the NEA-TDB update selection in 2003 [11] discussed the existence of the $\mathrm{Ca}_{2} \mathrm{UO}_{2}\left(\mathrm{CO}_{3}\right)_{3}(\mathrm{aq})$ complex but did not select any constant. The ternary alkaline earth carbonate uranyl species appear to be important as they may dominate the uranyl aqueous speciation in the $\mathrm{pH}$ range 7-9 in solution equilibrated with calcite. Such complexes may increase for instance the solubility of uranium and change its sorption properties [17,22,38-39].

Uranium solid phases. The evaluation of the uranyl solid phases that may control the uranium concentration in the waters was made on the basis of saturation indices. The data bases compiled 
and used by the participants differ significantly regarding the $\mathrm{U}(\mathrm{VI})$ solid phases considered and their solubility products (see Tables S1 of the Supplementary Information). In the case of waters $\mathbf{E}$ and $\mathbf{F}$, all solids were found to be undersaturated by all participants. On the contrary waters $\mathbf{A}$ to $\mathbf{D}$ were found to be oversaturated regarding different uranyl solid phases. Different results have been proposed, mainly as a result of different values of the solubility products, or due to the absence of some phases in the data base. It is difficult here to recommend a selection of solubility products, but it can be noted that such existing differences in data bases makes it difficult to rely on solubility calculation without a careful and exhaustive review of the solid phases present in the data base. Moreover, alkaline earth $\mathrm{M}_{2} \mathrm{UO}_{2}\left(\mathrm{CO}_{3}\right)_{3}$ solid phases were not selected due to non compliance of original reports [40] with the selection criteria [9]. The re-evaluations in [12] from data in [40] were not included by any of the participants.

It is worthy to note that participant $\mathbf{1}$ found that soddyite could be the solubility-limiting phase in waters $\mathbf{A}$ to $\mathbf{D}$. For the same water compositions, participant $\mathbf{4}$ calculated uranium solubilities at equilibrium with either calcium uranate or (meta)schoepite although the resulting solubilities were found to be higher than the uranium content as reported in Table 1, suggesting that these phases were undersaturated. Calcium uranate $\mathrm{CaUO}_{4}$ can usually be prepared and stabilized at high temperature. One may consider that it is not a relevant phase for low temperature modelling while it was concluded that a partially hydrated calcium uranate could explain uranium solubilities at the Hanford site [41]. Participant 2 indicated the unrealistically low uranium concentration when compregnacite precipitates; other phases such as becquerelite, uranophane, (meta)schoepite, and soddyite were found to possibly control uranium solubility only in water $\mathbf{C}$. The present exercise did not aim at determining which solid phase controlled the uranium concentrations, especially in the real waters $\mathbf{A}$ and $\mathbf{E}$, but rather at comparing differences in calculations made without constraints. The uranium minerals are usually not pure phases of perfect cristallinity - e.g. see discussion on the selection of schoepite data in [9] -, which certainly induces discrepancies in the determination of related thermodynamic equilibrium constants as compiled in data bases. Moreover one should be 
aware that non-stoichiometric dissolution, which may occur for some layered uranium silicates for instance, makes it difficult to know the appropriate dissolution equilibrium [42]. Thus the modeller has to rely on his knowledge of the geochemical system to identify the processes for controlling the uranium solubility and release. Experimental information such as X-ray diffraction or spectroscopic characterizations of the compounds, and solution analysis often is necessary to verify the chemical model.

\section{Conclusion}

The main outcome of this modelling exercise is that the alkaline earth ternary carbonate species and also maybe phases - of uranyl should be accounted for in data bases. Rather recent formation data were reported in the literature while scarcely included in compiled thermochemical data bases. Particularly the soluble species $\mathrm{Ca}_{2} \mathrm{UO}_{2}\left(\mathrm{CO}_{3}\right)_{3}(\mathrm{aq}), \mathrm{CaUO}_{2}\left(\mathrm{CO}_{3}\right)_{3}{ }^{2-}$, and $\mathrm{MgUO}_{2}\left(\mathrm{CO}_{3}\right)_{3}{ }^{2-}$ may dominate the uranyl speciation in natural water devoid of organic matter. The main differences between the calculated speciation were caused by the implementation or not of the corresponding formation equilibria in the entry data base. Significant differences can be observed in the formation constants of the alkaline earth ternary carbonate species of uranyl, which suggests that reviewing the experimental determinations would be valuable in order to provide a consistent set of values for reliable modelling. The calculation software or the type of ion activity models - in view of the moderate ionic strength -, were of minor importance in the present exercise. In general it should be recommended to ensure that the ion activity model is consistent with the values of thermodynamic data taken from a data base. It may induce a loss of consistency when mixing different models (for instance NEA-selected data should be used with a SIT formalism). The amount of uranium in solution could be calculated considering various possible solubility-controlling phases though such an estimation definitely requires the expertise of the geochemist and should be accompanied with experimental evidence.

\section{Acknowledgement}


The authors would like to acknowledge the support of the CETAMA of the CEA.

\section{References}

1. Altmaier, M. and Vercouter T., Aquatic chemistry of the actinides, in Radionuclide behaviour in the natural environment: Science, impacts and lessons for the nuclear industry, Poinssot, C. and Geckeis, H. Editors. 2012, Woodhead. p. 744.

2. Reiller, P.E., Marang, L., Jouvin, D., Benedetti, M. F.., Uranium (VI) binding to humic substances: Speciation, estimation of competition, and application to independent data, in The New Uranium Mining Boom. Challenge and Lessons Learned, Merkel, B. and Schipek, M., Editors. 2011, Springer-Verlag: Berlin. p. 565-572.

3. Li, D. and Kaplan, D.I., Sorption coefficients and molecular mechanisms of $\mathrm{Pu}, \mathrm{U}, \mathrm{Np}, \mathrm{Am}$ and Tc to Fe (hydr)oxides: A review. Journal of Hazardous Materials, 2012. 243: p. 1-18.

4. Denison, F.H. and Garnier-LaPlace, J., The effects of database parameter uncertainty on uranium(VI) equilibrium calculations. Geochimica et Cosmochimica Acta, 2005. 69(9): p. 2183-2191.

5. Billard, I., Ansoborlo, E., Apperson, K., Arpigny, S., Azenha, M. E., Birch, D., Bros, P., Burrows, H. D., Choppin, G., Couston, L., Dubois, V., Fanghaenel, T., Geipel, G., Hubert, S., Kim, J. I., Kimura, T., Klenze, R., Kronenberg, A., Kumke, M., Lagarde, G., Lamarque, G., Lis, S., Madic, C., Meinrath, G., Moulin, C., Nagaishi, R., Parker, D., Plancque, G., Scherbaum, F., Simoni, E., Sinkov, S., Viallesoubranne, C., Aqueous solutions of uranium(VI) as studied by time-resolved emission spectroscopy: A round-robin test. Applied Spectroscopy, 2003. 57(8): p. 1027-1038.

6. Bion, L., Ansoborlo, E., Moulin, V., Reiller, P., Collins, R., Gilbin, R., Fevrier, L., Perrier, T., Denison, F., Cote, G., Influence of thermodynamic database on the modelisation of americium(III) speciation in a simulated biological medium. Radiochimica Acta, 2005. 93(11): p. 715-718.

7. Wanner, H., The NEA thermochemical data base project. Radiochimica Acta, 1988. 44-5: p. 325-329.

8. Mompean, F.J. and Wanner, H., The OECD Nuclear Energy Agency Thermochemical Database Project. Radiochimica Acta, 2003. 91(11): p. 617-621.

9. Grenthe, I., Fuger, J., Konings, R.J.M., Lemire, R.J., Muller, A.B., Nguyen-Trung, C., Wanner, H., Chemical Thermodynamics of Uranium, ed. H. Wanner and I. Forest. Vol. 1. 1992, Amsterdam: North-Holland. 715.

10. Silva, R.J., Bidoglio, G., Rand, M.H., Robouch, P.B., Wanner, H., Puigdomènech, I., Chemical Thermodynamics of Americium. OECD Nuclear Energy Agency ed. Chemical Thermodynamics. Vol. 3. 1995, Amsterdam: Elsevier B.V. 374.

11. Guillaumont, R., Fanghänel, T., Fuger, J., Grenthe, I., Neck, V., Palmer, D.A., Rand, M.H., , Update on the Chemical Thermodynamics of Uranium, Neptunium, Plutonium, Americium and Technetium. Vol. 5. 2003, Amsterdam: Elsevier B.V. 919.

12. Gorman-Lewis, D., Burns, P.C., and Fein, J.B., Review of uranyl mineral solubility measurements. Journal of Chemical Thermodynamics, 2008. 40(3): p. 335-352.

13. Bernhard, G., Geipel, G., Brendler, V., Nitsche, H., Speciation of uranium in seepage waters of a mine tailing pile studied by time-resolved laser-induced fluorescence spectroscopy (TRLFS). Radiochimica Acta, 1996. 74: p. 87-91.

14. Bernhard, G., Geipel, G., Reich, T., Brendler, V., Amayri, S., Nitsche, H., UranyI(VI) carbonate complex formation: Validation of the $\mathrm{Ca}_{2} \mathrm{UO}_{2}\left(\mathrm{CO}_{3}\right)_{3}$ (aq.) species. Radiochimica Acta, 2001. 89(8): p. 511-518.

15. Kalmykov, S.N. and Choppin, G.R., Mixed $\mathrm{Ca}^{2+} / \mathrm{UO}_{2}{ }^{2+} / \mathrm{CO}_{3}{ }^{2-}$ complex formation at different ionic strengths. Radiochimica Acta, 2000. 88(9-11): p. 603-606. 
16. Bernhard, G., Geipel, G., Brendler, V., Nitsche, H., Uranium speciation in waters of different uranium mining areas. Journal of Alloys and Compounds, 1998. 271: p. 201-205.

17. Prat, O., Vercouter, T., Ansoborlo, E., Fichet, P., Perret, P., Kurttio, P., Salonen, L., Uranium Speciation in Drinking Water from Drilled Wells in Southern Finland and Its Potential Links to Health Effects. Environmental Science \& Technology, 2009. 43(10): p. 3941-3946.

18. Bradbury, M.H. and Baeyens, B., Predictive sorption modelling of Ni(II), Co(II), Eu(IIII), Th(IV) and U(VI) on MX-80 bentonite and Opalinus Clay: A "bottom-up" approach. Applied Clay Science, 2011. 52(1-2): p. 27-33.

19. Stewart, B.D., Mayes, M.A. and Fendorf, S., Impact of Uranyl-Calcium-Carbonato Complexes on Uranium(VI) Adsorption to Synthetic and Natural Sediments. Environmental Science \& Technology, 2010. 44(3): p. 928-934.

20. Wang, Z.M., Zachara, J. M., Gassman, P. L., Liu, C. X., Qafoku, O., Yantasee, W., Catalan, J. G., Fluorescence spectroscopy of U(VI)-silicates and U(VI)-contaminated Hanford sediment. Geochimica et Cosmochimica Acta, 2005. 69(6): p. 1391-1403.

21. Wang, Z.M., Zachara, J. M., Boily, J. F., Xia, Y. X., Resch, T. C., Moore, D. A., Liu, C., Determining individual mineral contributions to $U(V I)$ adsorption in a contaminated aquifer sediment: A fluorescence spectroscopy study. Geochimica et Cosmochimica Acta, 2011. 75(10): p. 2965-2979.

22. Dong, W. and Brooks, S.C., Determination of the Formation Constants of Ternary Complexes of Uranyl and Carbonate with Alkaline Earth Metals $\left(\mathrm{Mg}^{2+}, \mathrm{Ca}^{2+}, \mathrm{Sr}^{2+}\right.$, and $\left.\mathrm{Ba}^{2+}\right)$ Using Anion Exchange Method. Environmental Science \& Technology, 2006. 40(15): p. 4689-4695.

23. Dong, W.M. and Brooks, S.C., Formation of aqueous $\mathrm{MgUO}_{2}\left(\mathrm{CO}_{3}\right)_{3}^{2-}$ complex and uranium anion exchange mechanism onto an exchange resin. Environmental Science \& Technology, 2008. 42(6): p. 1979-1983.

24. Geipel, G., Amayri, S. and Bernhard, G., Mixed complexes of alkaline earth uranyl carbonates: A laser-induced time-resolved fluorescence spectroscopic study. Spectrochimica Acta Part AMolecular and Biomolecular Spectroscopy, 2008. 71(1): p. 53-58.

25. Lee, J. Y., and Yun, J. I., Formation of ternary $\mathrm{CaUO}_{2}\left(\mathrm{CO}_{3}\right)_{3}{ }^{2-}$ and $\mathrm{Ca}_{2} \mathrm{UO}_{2}\left(\mathrm{CO}_{3}\right)_{3}(\mathrm{aq})$ complexes under neutral to weakly alkaline conditions. Dalton Transactions, 2013. 42(27): p. 9862-9869.

26. Grenthe, I., Plyasunov, A., and Spahiu, K., Estimation of medium effects on thermodynamic data. Modelling in Aquatic Chemistry, ed. I. Grenthe and I. Puigdomènech. 1997, Paris: OECD.

27. Ekberg, C. and Odegaard-Jensen, A., Uncertainties in chemical modelling of solubility, speciation and sorption. Accreditation and Quality Assurance, 2011. 16(4-5): p. 207-214.

28. Smith, D.S., Adams, N.W.H., and Kramer, J.R., Resolving uncertainty in chemical speciation determinations. Geochimica et Cosmochimica Acta, 1999. 63(19-20): p. 3337-3347.

29. Meinrath, G., Ekberg, C., Landgren, A., Liljenzin, J. O., Assessment of uncertainty in parameter evaluation and prediction. Talanta, 2000. 51(2): p. 231-246.

30. Parkhurst, D.L. and Appelo, C.A.J., User_s guide to PHREEQC (Version 2). A computer program for speciation, batch-reaction, one-dimensional transport, and inverse geochemical calculations, 2001. p. 99-4259.

31. Van der Lee, J. and De windt, L., JCHESS, 1999, Ecole des Mines de Paris.

32. Puigdomènech, I., MEDUSA: Make Equilibrium Diagrams Using Sophisticated Algorithms, version 2., in Inorganic Chemistry 1999, Stockholm Royal Institute of Technology (KTH).

33. Wolery, T.J., EQ3/6, a Software Package for Geochemical Modeling of Aqueous Systems: Package Overview and Installation Guide (Version 7.2b), 1995, Lawrence Livermore National Laboratory, Livermore, California.

34. Van der Lee, J. and Lomenech, C., Towards a common thermodynamic database for speciation models. Radiochimica Acta, 2004. 92(9-11): p. 811-818.

35. Denison, F., Application of chemical speciation modelling to uranium toxicity and bioavailability studies: compilation of a coherent database for simple experimental systems and an investigation of the database uncertainty on the model predictions, 2002, IRSN. p. 162. 
36. Grivé, M., Personal communication.

37. Gorman-Lewis, D., Fein, J. B., Burns, P. C., Szymanowski, J. E. S., Converse, J., Solubility measurements of the uranyl oxide hydrate phases metaschoepite, compreignacite, $\mathrm{Na}$ compreignacite, becquerelite, and clarkeite. Journal of Chemical Thermodynamics, 2008. 40(6): p. 980-990.

38. Fox, P.M., Davis, J.A. and Zachara, J.M., The effect of calcium on aqueous uranium(VI) speciation and adsorption to ferrihydrite and quartz. Geochimica et Cosmochimica Acta, 2006. 70(6): p. 1379-1387.

39. Zheng, Z., Tokunaga, T.K., and Wan, J., Influence of Calcium Carbonate on U(VI) Sorption to Soils. Environmental Science \& Technology, 2003. 37(24): p. 5603-5608.

40. Alwan, A. K., and Williams, P. A., Aqueous chemistry of uranium minerals. Part 2. Minerals of the liebigite group. Mineralogical Magazine, 1980, 43, 665-667.

41. Cantrell, K. J., Heald, S. M., Arey, B. W., and Lindberg, M. J., Inhibited Release of Mobile Contaminants from Hanford Tank Residual Waste. Proceedings of the Waste Management Conference, February 27 - March 3, 2011, Phoenix, AZ, USA.

42. Burns, P.C., and Finch, R. Uranium: mineralogy, geochemistry and the environment. In: Burns, P.C. and Finch, R. Editors, Reviews in Mineralogy, Volume 38. Mineralogical Society of America, Washington DC, 1999. 